\title{
Comparing Performance of Synthetic Sex Attractants and a Semisynthetic Bisexual Lure in Orthosia and Conistra Species (Lepidoptera: Noctuidae)
}

\author{
SZ. SZANYI ${ }^{1 *}$, I. SZARUKÁN ${ }^{1}$, A. NAGY ${ }^{1}$, J. JÓSVAI $^{3}$, Z. IMREI $^{3}$, \\ Z. VARGA ${ }^{2}$ and M. TÓTH ${ }^{3}$ \\ ${ }^{1}$ Faculty of the Agricultural and Food Sciences and Environmental Management, Institute of Plant Protection, \\ University of Debrecen, H-4002 Debrecen, P.O.Box 400, Hungary \\ ${ }^{2}$ Department of Evolutionary Zoology, University of Debrecen, H-4010 Debrecen, Egyetem tér 1, Hungary \\ ${ }^{3}$ Plant Protection Institute, Centre for Agricultural Research, Hungarian Academy of Sciences, \\ H-1525 Budapest, P.O.Box 102, Hungary
}

(Received: 22 January 2020; accepted: 3 February 2020)

\begin{abstract}
The performance of a semisynthetic bisexual lure (SBL, containing isoamyl alcohol, acetic acid and red wine) previously found attractive for a number of noctuids was compared with that of the respective synthetic sex attractants of Orthosia cerasi (= stabilis), O. cruda, O. gothica, O. incerta, Anorthoa munda and Conistra vaccini. The respective sex attractants performed significantly better in the Orthosia spp. than the SBL lure, which, although regularly catching low numbers of both females and males, did not differ significantly from zero catch in unbaited control traps. On the other hand, the SBL lure performed as well as the sex attractant in C. vaccini. Sizeable catches of C. rubiginea, C. rubiginosa and C. erythrocephala were also recorded in traps with the SBL lure. The SBL lure can prove to be a useful tool in ecological and faunistical studies of Conistra and related hibernating Xylenini species.
\end{abstract}

Keywords: Semisynthetic bisexual lure, isoamyl alcohol, acetic acid, red wine, sex attractant.

The larvae of species of the noctuid genus Orthosia feed on leaves of various trees in late spring/early summer, and some species are known to cause damages to orchard and forest trees as well (Cayrol, 1966). Adults have a single flight period per year, in early spring (March, April, according to climatic conditions). Sex attractants have been described among the pest Orthosia in Europe for Orthosia cruda (Denis et Schiffermüller, 1775), Orthosia incerta (Hufnagel, 1766), Orthosia gothica (Linnaeus, 1758), Orthosia cerasi (Fabricius, 1775) (= stabilis (Denis et Schiffermüller, 1775)) and Anorthoa munda (Denis et Schiffermüller, 1775) (Booij and Voerman, 1984; Tóth et al., 1992, 1993), and traps baited with these are available for detection and monitoring. However, sex attractant baited traps will catch only males. Traps capable of capturing females could provide more useful data for monitoring of population dynamics. For example, data on captured females give information on the female flight pattern, by dissection of females we obtain data on

*Corresponding author; e-mail: szanyi.szabolcs@agr.unideb.hu 
the timing of fertilisation and oviposition, and thus these surveys could result in more precise pest control decisions (Wall, 1989; Witzgall et al., 2010).

A female-targeted noctuid feeding attractant containing isoamyl alcohol plus acetic acid has been described in North America (Landolt, 2000) and this lure proved to be attractive also on European noctuids as well (Tóth et al., 2010). Recently, we managed to increase the effect of this known synthetic attractant by the addition of natural ingredients such as wine extracts or wine, and this improved semisynthetic bisexual lure (SBL) attracted more than a hundred noctuid species (both females and males) in field tests in Hungary and Transcarpathia (Nagy et al., 2014, 2015; Szanyi et al., 2015; Tóth et al., 2015). A considerable number of species attracted belonged to the subfamily Hadeninae, including Orthosia species. Therefore, it appeared to be worthwhile to test this semisynthetic bisexual lure for attractancy on pest Orthosia species as well.

This present research was undertaken to compare the activity of the SBL lure with that of the respective synthetic sex attractants of some Orthosia spp. We were encouraged to embark on such a study, since in a preliminary experiment in 2012 traps baited with the mixture of iso-amyl alcohol plus acetic acid captured 97 Orthosia specimens (O. cerasi: $28 \%$, O. cruda $33 \%$, O. gothica: $8 \%$, O. incerta: $15 \%$ and A. munda: $16 \%$ ) while unbaited traps caught a single $O$. cerasi. (Tóth et al., unpublished). Similarly, the capture of three specimens of Orthosia hibisci (Guenée, 1852) has been reported in traps with the same lure composition in a screening test in Alaska (Landolt et al., 2007).

Data on other noctuids being on the wing in early spring (i.e. hibernated Conistra spp.) are also presented.

\section{Materials and Methods}

\section{Field tests}

Tests were conducted in a mixed oak forest at the Julianna major Experimental Station of the Plant Protection Institute of the Centre for Agricultural Research, Hungarian Academy of Sciences (PPI CAR HAS, Budapest, Hungary) using accepted methods in trapping experiments of the same nature (Roelofs and Cardé, 1977). Traps were arranged in a large circle, in random order, separated by $8-10 \mathrm{~m}$. Traps were inspected at some days' intervals (preferably twice weekly), when captured insects were recorded and removed. At the same time traps were moved one position forward in the circle to minimize positional effects.

The catch data from field trapping tests were transformed using $\sqrt{ }(\mathrm{x}+0.5)$ (Roelofs and Cardé, 1977) and analyzed by repeated measure ANOVA. If the ANOVA yielded significance, then treatment means were separated by the Student-Newman-Keuls test. If one of the treatments caught no insects, the Bonferroni-Dunn test was used to compare mean catches in other treatments with zero catch. All statistical procedures were conducted using the software packages StatView ${ }^{\circledR}$ v4.01 and SuperANOVA ${ }^{\circledR}$ v1.11 (Abacus Concepts, Berkeley, CA, USA). 


\section{Traps}

In the tests, funnel traps CSALOMON $®$ VARL were used. These traps have routinely been used for trapping several moth species of larger size (Tóth et al., 2000, 2010; Subchev et al., 2004); photos of the trap can be viewed at www.csalomontraps.com. For killing captured insects, a small piece $(1 \times 1 \mathrm{~cm})$ of a household anti-moth insecticide strip (Chemotox ${ }^{\circledR}$ SaraLee, Temana Intl. Ltd, Slouth, UK; active ingredient $15 \%$ dichlorvos) was placed into the catch container of traps.

\section{Baits}

The SBL lure tested was the same as described earlier (Tóth et al., 2015), with the active ingredients of isoamyl alcohol, acetic acid and red wine $(1: 1: 1)$.

Sex attractant lures were obtained commercially from the CSALOMON® trap family (PPI CAR HAS, Budapest, Hungary). Active ingredients were as described previously (Booij and Voerman, 1984; Tóth et al., 1992, 1993): O. cerasi (Z)-11-hexadecenal plus (Z)-9-tetradecenal (1:10); O. cruda: (Z)-11-hexadecenyl acetate plus (Z)-9-tetradecenyl acetate (20:1); O. gothica: $(Z)$-9-tetradecenyl acetate plus (Z)-9-tetradecen-1-ol plus (Z)-5-tetradecenyl acetate plus (Z)-11-tetradecenyl acetate (20:20:1:1); O. incerta: (Z)-11-hexadecenal plus (Z)-9-tetradecenal (100:1); A. munda: (Z)-11-hexadecen-1-ol plus (Z)-11-hexadecenal (20:1). The sex attractant for Conistra vaccini (Linnaeus, 1761) consisted of (Z)-7-tetradecenyl acetate (Tóth et al., unpublished).

\section{Experimental details}

Experiment 1. Treatments tested were the SBL lure, the synthetic sex attractants of O. cerasi, O. cruda, O. gothica, O. incerta, A. munda and C. vaccini, and unbaited controls. From each treatment 5 traps were set out, giving a total number of 40 traps. The test was run March 18-April 21, 2016.

Experiment 2. Treatments tested were the same as in Exp. 1. Six traps with the SBL lure while 2 traps of each of the sex attractants or unbaited controls were set out, giving a total number of 20 traps. The test was run March 16-April 24, 2017.

\section{Results}

In Exp. 1. traps with sex attractants of all Orthosia spp. and of $C$. vaccini caught significantly more than unbaited control traps or traps baited with the SBL lure. Low catches of $O$. cruda, O. gothica and A. munda in traps with the SBL lure did not differ from zero catch in unbaited traps. On the other hand, both the SBL lure and the respective sex attractant caught more $C$. vaccini than the other treatments. Catches with the SBL lure or the sex attractant did not differ in this species. Some specimens of Conistra erythrocephala (Denis et Schiffermüller, 1775), Eupsilia transversa (Hufnagel, 1766), and Scolioperyx libatrix (Linnaeus, 1758) were caught, all in traps with the SBL lure, and a single specimen of Acronicta euphorbiae (Denis et Schiffermüller, 1775) was recorded in traps with the sex attractant of $O$. incerta (Table 1). 
Table 1

Mean catch $( \pm$ SE) per trap per inspection of Orthosia spp. and Conistra spp. in traps baited with the bisexual lure or with the respective sex attractant in Exp. 1.

\begin{tabular}{|c|c|c|c|c|c|c|c|c|c|}
\hline Species caught & $\begin{array}{l}\text { Semi- } \\
\text { synthetic } \\
\text { bisexual } \\
\text { lure } \\
(\mathrm{SBL})\end{array}$ & $\begin{array}{l}\text { O. cerasi } \\
\text { sex attr. } \\
\text { lure }\end{array}$ & $\begin{array}{l}\text { O. cruda } \\
\text { sex attr. } \\
\text { lure }\end{array}$ & $\begin{array}{l}\text { O. gothica } \\
\text { sex attr. } \\
\text { lure }\end{array}$ & $\begin{array}{l}\text { O. incerta } \\
\text { sex attr. } \\
\text { lure }\end{array}$ & $\begin{array}{l}\text { A. munda } \\
\text { sex attr. } \\
\text { lure }\end{array}$ & $\begin{array}{l}\text { C. vaccini } \\
\text { sex attr. } \\
\text { lure }\end{array}$ & $\begin{array}{l}\text { Unbaited } \\
\text { control }\end{array}$ & $\begin{array}{l}\text { Total } \\
\text { caught }\end{array}$ \\
\hline O. cerasi & $0.08 \mathrm{a}$ & $1.16 b$ & $0.00 \mathrm{a}$ & $0.00 \mathrm{a}$ & $0.00 \mathrm{a}$ & $0.00 \mathrm{a}$ & $0.00 \mathrm{a}$ & $0.00 \mathrm{a}$ & 62 \\
\hline O. cruda & $0.02 \mathrm{a}$ & $0.00 \mathrm{a}$ & $3.26 \mathrm{~b}$ & $0.00 \mathrm{a}$ & $0.00 \mathrm{a}$ & $0.00 \mathrm{a}$ & $0.00 \mathrm{a}$ & $0.00 \mathrm{a}$ & 164 \\
\hline O. gothica & $0.02 \mathrm{a}$ & $0.00 \mathrm{a}$ & $0.00 \mathrm{a}$ & $0.62 b$ & $0.00 \mathrm{a}$ & $0.00 \mathrm{a}$ & $0.00 \mathrm{a}$ & $0.00 \mathrm{a}$ & 32 \\
\hline O. incerta & $0.00 \mathrm{a}$ & $0.00 \mathrm{a}$ & $0.00 \mathrm{a}$ & $0.00 \mathrm{a}$ & $0.38 \mathrm{a}$ & $0.00 \mathrm{a}$ & $0.00 \mathrm{a}$ & $0.00 \mathrm{a}$ & 19 \\
\hline A. munda & $0.22 \mathrm{a}$ & $0.00 \mathrm{a}$ & $0.00 \mathrm{a}$ & $0.00 \mathrm{a}$ & $0.00 \mathrm{a}$ & $1.82 \mathrm{~b}$ & $0.00 \mathrm{a}$ & $0.00 \mathrm{a}$ & 103 \\
\hline C. vaccini & $1.06 \mathrm{~b}$ & $0.00 \mathrm{a}$ & $0.00 \mathrm{a}$ & $0.00 \mathrm{a}$ & $0.00 \mathrm{a}$ & $0.00 \mathrm{a}$ & $0.48 b$ & $0.00 \mathrm{a}$ & 77 \\
\hline C. erythrocephala & $0.20 \mathrm{a}$ & $0.00 \mathrm{a}$ & $0.00 \mathrm{a}$ & $0.00 \mathrm{a}$ & $0.00 \mathrm{a}$ & $0.00 \mathrm{a}$ & $0.00 \mathrm{a}$ & $0.00 \mathrm{a}$ & 10 \\
\hline
\end{tabular}

Significance: means with same letter within one row are not significantly different at $\mathrm{P}=5 \%$ by ANOVA followed by Student-Newman-Keuls and Bonferroni-Dunn posthocs.

In Exp. 2. very low catches were recorded. The tendency of catches of Orthosia spp. with their respective sex attractants was very similar to catches in Exp. 1. with the exception that in $O$. cerasi this time the low catches did not differ from unbaited. Again, some Orthosia spp. specimens were recorded in traps with the SBL lure, but they did not differ from zero catch in unbaited traps. On the other hand, sizeable catches of $C$. vaccini were found in traps with the SBL lure or in those baited with the C. vaccini sex attractant, significantly more than in any other treatments. Catches of these two treatments did not differ from each other. The traps with the SBL lure caught significantly more than other treatments also from $C$. erythrocephala, Conistra rubiginea (Denis et Schiffermüller, 1775) and Conistra rubiginosa (Scopoli, 1763). Low numbers of E. transversa, S. libatrix and Lithophane ornitopus (Hufnagel, 1766) were caught in traps with the SBL lure, and a single L. ornitopus specimen was found in traps with the $O$. gothica sex attractant (Table 2).

\section{Discussion}

In both years of the study the population density of Orthosia spp. appeared to be very low, as evidenced by the relatively low catches of all spp. in traps with their respective sex attractants (pls refer to catch figures in Tóth et al., 1992, 1993). In such circumstances the performance of the sex attractants in all spp. exceeded that of the SBL lure in the present study. We conclude that the activity of the SBL lure (if any) does not reach the level of practical applicability. Consequently, despite the fact that among the SBL catches females were also represented, the SBL lure cannot be recommended for use in detection and monitoring for agricultural or forestry purposes.

On the other hand, the SBL lure showed surprisingly high attractivity in C. vaccini, performing at a similar level as its sex attractant. Sizeable catches were recorded, especially in the second year also from other Conistra spp., so SBL appears to be a strong attractant for Conistra. 
Table 2

Mean catch $( \pm$ SE) per trap per inspection of Orthosia spp. and Conistra spp. in traps baited with the bisexual lure or with the respective sex attractant in Exp. 2.

\begin{tabular}{llllllllll}
\hline Species caught & $\begin{array}{l}\text { Semi- } \\
\text { synthetic } \\
\text { bisexual } \\
\text { lure } \\
\text { (SBL) }\end{array}$ & $\begin{array}{l}\text { O.cerasi } \\
\text { sex attr. } \\
\text { lure }\end{array}$ & $\begin{array}{l}\text { O. cruda } \\
\text { sex attr. } \\
\text { lure }\end{array}$ & $\begin{array}{l}\text { O. gothica } \\
\text { sex attr. } \\
\text { lure }\end{array}$ & $\begin{array}{l}\text { O. incerta } \\
\text { sex attr. } \\
\text { lure }\end{array}$ & $\begin{array}{l}\text { A. munda } \\
\text { sex attr. } \\
\text { lure }\end{array}$ & $\begin{array}{l}\text { C. vaccini } \\
\text { sex attr. } \\
\text { lure }\end{array}$ & $\begin{array}{l}\text { Unbaited } \\
\text { control }\end{array}$ & $\begin{array}{l}\text { Total } \\
\text { caught }\end{array}$ \\
& $0.43 \mathrm{a}$ & $0.57 \mathrm{a}$ & $0.14 \mathrm{a}$ & $0.00 \mathrm{a}$ & $0.00 \mathrm{a}$ & $0.00 \mathrm{a}$ & $0.00 \mathrm{a}$ & $0.00 \mathrm{a}$ & 29 \\
\hline O. cerasi & $0.05 \mathrm{a}$ & $0.00 \mathrm{a}$ & $1.50 \mathrm{~b}$ & $0.00 \mathrm{a}$ & $0.00 \mathrm{a}$ & $0.00 \mathrm{a}$ & $0.00 \mathrm{a}$ & $0.00 \mathrm{a}$ & 23 \\
O. cruda & $0.02 \mathrm{a}$ & $0.00 \mathrm{a}$ & $0.00 \mathrm{a}$ & $1.79 \mathrm{~b}$ & $0.00 \mathrm{a}$ & $0.00 \mathrm{a}$ & $0.00 \mathrm{a}$ & $0.00 \mathrm{a}$ & 26 \\
O. gothica & $0.12 \mathrm{a}$ & $0.00 \mathrm{a}$ & $0.00 \mathrm{a}$ & $0.00 \mathrm{a}$ & $1.43 \mathrm{~b}$ & $0.00 \mathrm{a}$ & $0.00 \mathrm{a}$ & $0.00 \mathrm{a}$ & 25 \\
O. incerta & $0.21 \mathrm{a}$ & $0.00 \mathrm{a}$ & $0.00 \mathrm{a}$ & $0.00 \mathrm{a}$ & $0.00 \mathrm{a}$ & $1.21 \mathrm{~b}$ & $0.00 \mathrm{a}$ & $0.00 \mathrm{a}$ & 26 \\
A. munda & $7.43 \mathrm{~b}$ & $0.00 \mathrm{a}$ & $0.00 \mathrm{a}$ & $0.00 \mathrm{a}$ & $0.00 \mathrm{a}$ & $0.00 \mathrm{a}$ & $9.07 \mathrm{~b}$ & $0.00 \mathrm{a}$ & 439 \\
C. vaccini & $0.88 \mathrm{~b}$ & $0.00 \mathrm{a}$ & $0.00 \mathrm{a}$ & $0.00 \mathrm{a}$ & $0.00 \mathrm{a}$ & $0.00 \mathrm{a}$ & $0.00 \mathrm{a}$ & $0.00 \mathrm{a}$ & 37 \\
C. erythrocephala & $0.50 \mathrm{~b}$ & $0.00 \mathrm{a}$ & $0.00 \mathrm{a}$ & $0.00 \mathrm{a}$ & $0.00 \mathrm{a}$ & $0.00 \mathrm{a}$ & $0.00 \mathrm{a}$ & $0.00 \mathrm{a}$ & 21 \\
C. rubiginea & $1.55 \mathrm{~b}$ & $0.00 \mathrm{a}$ & $0.00 \mathrm{a}$ & $0.00 \mathrm{a}$ & $0.00 \mathrm{a}$ & $0.00 \mathrm{a}$ & $0.00 \mathrm{a}$ & $0.00 \mathrm{a}$ & 65 \\
C. rubiginosa & & & & & & & & & \\
\hline
\end{tabular}

Significance: refer to Table 1.

In this comparative study we included only the sex attractant of $C$. vaccini. Although a sex attractant consisting of $(Z)$-11-hexadecenyl acetate and $(Z)$-11-hexadeceal has been described also for $C$. rubiginea (Subchev et al., 1986), in numerous field tests of our own of various mixtures of these two compounds we never observed catches of more than a handful of specimens from this species (Tóth et al., unpublished), so we felt that the sex attractant has not been sufficiently optimized. Conistra species are not regarded as pests, so probably the activity of the SBL lure cannot be exploited for agricultural or forestry applications, however, it can prove to be useful in ecological and faunistical studies for this group of insects, as already evidenced in a large number of other noctuid taxa (Nagy et al., 2014, 2015; Szanyi et al., 2015).

Other noctuids (E. transversa, S. libatrix and L. ornitopus) in the catch of traps with the SBL lure in this study are typical species in tests performed in the course of the summer season (Nagy et al., 2014, 2015; Szanyi et al., 2015).

The strikingly low attractivity of synthetic lures on Orthosia species vs. the high efficiency in capturing of hibernated Conistra and related Xylenini species (Eupsilia spp., Litophane spp.) can be explained that the freshly emerged Orthosia species are mostly feeding on amenta of willow (Salix) species.

Isoamyl alcohol, the major synthetic component of the SBL lure was originally identified from fermenting liquids and is thought to affect noctuids which prefer to feed on such fermenting sources (Landolt, 2000). Another group of synthetic feeding attractants is based on floral compounds like phenylacetaldehyde (Cantelo and Jacobson, 1979; Creighton et al., 1973). Phenylacetaldehyde-based lures attract predominantly such noctuids (Plusiinae and Melicleptriinae mainly) which prefer flowers for feeding source (Landolt et al., 2001, 2006; Tóth et al., 2010). Since Orthosia spp. adults are frequently observed to feed on catkins, the flowers of willow trees, it may show perspectives to test phenylacetaldehyde-based attractants for this group of pests in future assays. 


\section{Acknowledgements}

The authors are indebted to HAS Domus Junior Bursary for supporting Szabolcs Szanyi's work.

\section{Literature}

Booij, C. J. H. and Voerman, S. (1984): Sex attractants for the fruit-attacking noctuids Orthosia incerta and Orthosia cruda. Entomol. Exp. Appl. 36, 15-16.

Cantelo, W. W. and Jacobson, M. (1979): Phenylacetaldehyde attracts moths to bladder flower and to blacklight traps. Environ. Entomol. 8, 444-447.

Cayrol, R. A. (1966): Famille des Noctuidae. In: A. S. Balachowsky (ed.): Entomologie appliquée á l'agriculture Vol. 2. Mason et Cie, Paris 1255-1471.

Creighton, C. S., McFadden, T. L. and Cuthbert, E. R. (1973): Supplementary data on phenylacetaldehyde: an attractant for Lepidoptera. J. Econ. Entomol. 66, 114-116.

Landolt, P. J. (2000): New chemical attractants for trapping Lacanobia subjuncta, Mamestra configurata, and Xestia c-nigrum (Lepidoptera: Noctuidae). J. Econ. Entomol. 93, 101-106.

Landolt, P. J., Adams, T., Reed, H. C. and Zack, R. S. (2001): Trapping alfalfa looper adults, Autographa californica (Speyer) (Lepidoptera: Noctuidae) with single and double component floral chemical lures. Environ. Entomol. 30, 667-672.

Landolt, P. J., Adams, T. and Zack, R. S. (2006): Field response of alfalfa looper and cabbage looper moths (Lepidoptera: Noctuidae, Plusiinae) to single and binary blends of floral odorants. Environ. Entomol. 35, 276-281.

Landolt, P. J., Pantoja, A., Hagerty, A., Crabo, L. and Green D. (2007): Moths trapped in Alaska with feeding attractant lures and the seasonal flight patterns of potential agricultural pests. Can. Ent. 139, 278-291.

Nagy, A., Szarukán, I., Gém, F., Nyitrai, R. and Tóth, M. (2014): Studies on the improvement of synthetic attractants for noctuids (Lepidoptera: Noctuidae). Acta Agraria Debreceniensis, 62, 86-91. (in Hungarian)

Nagy, A., Szarukán, I., Gém, F., Nyitrai, R, Füsti-Molnár, B., Németh, A., Kozák, L., Molnár, A., Katona, K., Szanyi, Sz., Varga, Z. and Tóth, M. (2015): Preliminary data on the effect of semi-synthetic baits for Noctuidae (Lepidoptera) on the non-target Lepidoptera species. Acta Agraria Debreceniensis, 66, 71-80.

Roelofs, W. L. and Cardé, R. T. (1977): Responses of Lepidoptera to synthetic sex pheromone chemicals and their analogues. Annu. Rev. Entomol. 22, 377-405.

Subchev, M., Toshova, T., Tóth, M., Voigt, E., Mikulás, J. and Francke, W. (2004): Catches of vine bud moth Theresimima ampelophaga (Lep., Zygaenidae: Procridinae) males in pheromone traps: effect of the purity and age of baits, design, colour and height of the traps, and daily sexual activity of males. Z. angew. Ent. 128, 44-50.

Subchev, M. A., Ganev, J. A. and Stoilov, I. L. (1986): Noctuid male sex attractants - cis-11-hexadecenyl compounds alone and in mixtures. Ekologiya, 18, 33-39.

Szanyi, Sz., Nagy, A., Molnár, A., Tóth, M. and Varga, Z. (2015): Pest species of Macrolepidoptera in the game reserve Velyka Dobron (Transcarpathia, Ukraine). Acta Agraria Debreceniensis, 66, 58-64.

Tóth, M., Szőcs, G. and Bengtsson, M. (1992): A sex attractant for male Orthosia gothica L. (Lepidoptera: Noctuidae). Z. Naturforsch. 47c, 613-617.

Tóth, M., Szőcs, G. and Bengtsson, M. (1993): Optimization of male sex attractants for Orthosia cruda Schiff., O. munda Schiff. and O. stabilis Schiff. (Lep.: Noctuidae). J. Appl. Entomol., 115, 342-349.

Tóth, M., Imrei, Z. and Szőcs, G. (2000): Non-sticky, non-saturable, high capacity new pheromone traps for Diabrotica virgifera virgifera (Coleoptera: Chrysomelidae) and Helicoverpa (Heliothis) armigera (Lepidoptera: Noctuidae). Integrált termesztés a kertészeti és szántóföldi kultúrákban, 21, 44-49. (in Hungarian)

Tóth, M., Szarukán, I., Dorogi, B., Gulyás, A., Nagy, P. and Rozgonyi, Z. (2010): Male and female noctuid moths attracted to synthetic lures in Europe. J. Chem. Ecol., 36, 592-598.

Tóth, M., Szarukán, I., Nagy, A., Gém, F., Nyitrai, R., Kecskés, Zs., Krakkó, L., Jósvai, J. and Bélai, I. (2015): Semisynthetic "bisex" lures for catching females and males of pest insects. Növényvédelem, 51, 197205. (in Hungarian) 
Wall, C. (1989): Evaluation and use of behaviour-modifying chemicals. In: A. R. Jutsum, and R. F. S. Gordon (eds): Insect Pheromones in Plant Protection. Wiley, Chicester, pp. 39-60.

Witzgall, P., Kirsch, P. and Cork, A. (2010): Sex pheromones and their impact on pest management. J. Chem. Ecol., 36, 80-100.

Open Access statement. This is an open-access article distributed under the terms of the Creative Commons Attribution 4.0 International License (https://creativecommons.org/licenses/by/4.0/), which permits unrestricted use, distribution, and reproduction in any medium, provided the original author and source are credited, a link to the CC License is provided, and changes - if any - are indicated. (SID_1) 
